19 Brinded BP, Taylor AJ. A mass killing in New Zealand. Aust N Z J Psychiatry 1995;29:316-20.

20 Beyersdorf SR, Nania JN, Luna GK. Community medical response to the Fairchild mass casualty event. Am J Surg 1996;171:467-70.

21 Curry JL. A disaster that could happen any where--the Palm Bay massacre. J Emerg Nurs 1990;16:42-8A.

22 Early E. Darnall Army Community Hospital's response to the Killeen massacre. J Emerg Nurs 1992;18:316-8.

23 Eckert WG. The St Valentine's Day massacre. Am J Forens Med Pathol 1980;1:67-70.

24 Meloy JR. Predatory violence during mass murder. J Forens $\mathrm{Sci}$ 1997;42:326-9.

25 Reay DT, Haglund WD, Bonnell HJ. Wah Mee massacre: the murder of 13 Chinese adults in a Seattle gambling club. Am J Forens Med Pathol 1986;7:330-6.

26 Coupland RM. Classification and management of war wounds. In: Johnson CD, Taylor I, eds. Recent advances in surgery. No 17. London: Churchill Livingstone, 1994:121-34.

27 Sellier KG, Kneubuehl BP. Wound ballistics. Amsterdam: Elsevier, 1994.
28 Kneubuehl BP. Small calibre weapon systems. In: Expert meeting on certain weapon systems and on implementation mechanisms in international law. Geneva: International Committee of the Red Cross, 1994:26-39.

29 Grossman D. On killing: the psychological cost of learning to kill in war and society. Boston: Little, Brown, 1995.

30 Anonymous. Nonlethal weapons: emerging requirements for security strategy. Washington, DC: Institute for Foreign Policy Analysis, 1996.

31 Arkin WM. Acoustic anti-personnel weapons: an inhumane future? Medicine, Conflict and Survival 1997;14:314-26.

32 Coupland RM. "Non-lethal" weapons: precipitating a new arms race. $B M J$ 1997;315:72.

33 Dando M. A new form of warfare: the rise of non-lethal weapons. London: Brassey's, 1996.

34 Lewer N, Schofield S. Non-lethal weapons: a fatal attraction? London: Zed Books, 1997.

35 Pengelly R. Wanted: a watch on non-lethal weapons. Int Defence Rev 1994;27:1.

36 Spinney L. A fate worse than death. New Scientist 1997 Oct 18:26-7. (Accepted 7 April 1999)

\title{
Effect of type and transfer of conventional weapons on civilian injuries: retrospective analysis of prospective data from Red Cross hospitals
}

\author{
Robin M Coupland, Hans O Samnegaard
}

\begin{abstract}
Editorial by Smith
Unit of the Chief Medical Officer, International

Committee of the Red Cross,

19 avenue de la Paix, 1202 Geneva Switzerland

Robin M Coupland

surgeon

Hans O

Samnegaard

surgeon

Correspondence to: Mr Coupland rcoupland@icrc.org
\end{abstract}

BMJ 1999;319:410-2

\begin{abstract}
Objective To examine the link between different weapons used in modern wars and their potential to injury civilians.

Design Retrospective analysis of prospectively collected data about hospital admissions.

Setting Hospitals of the International Committee of the Red Cross.

Subjects 18877 people wounded by bullets, fragmentation munitions, or mines. Of these, 2012 had been admitted to the hospital in Kabul within six hours of injury.

Main outcome measures Age and sex of wounded people according to cause of injury and whether they were civilians (women and girls, boys under 16 years old, or men of 50 or more).

Results $18.7 \%$ of those injured by bullets, $34.1 \%$ of those injured by fragments, and $30.8 \%$ of those injured by mines were civilians. Of those admitted to the Red Cross hospital in Kabul within six hours of injury, $39.1 \%$ of those injured by bullets, $60.6 \%$ of those injured by fragments, and $55.0 \%$ of those injured by mines were civilians.

Conclusions The proportion of civilians injured differs between weapon systems. The higher proportion injured by fragments and mines is explicable in terms of the military efficiency of weapons, the distance between user and victim, and the effect that the kind of weapon has on the psychology of the user.
\end{abstract}

\section{Introduction}

The use of weapons against people or targets containing people inevitably has a direct impact on the health of those people. ${ }^{12}$ This impact is related to factors dependent on the design of weapons and on their use. The nature of injury is closely related to the design of the weapon; wounds from bullets, fragments, and buried antipersonnel mines are distinguishable ${ }^{3-6}$ Factors dependent on the user, such as discipline and desire to avoid or injure civilians, determine the number and kind of people injured ${ }^{5-10}$ and may, in the case of bullets, determine which part of the body is injured. This century has seen an increased proportion of civilians injured during war. ${ }^{10}$ This is usually ascribed to military weapons passing into the hands of those with no respect for the civilian population or the Fourth Geneva Convention, which protects civilians. In parallel, there has been an extraordinary development of the military efficiency of weapons. ${ }^{11}$ This generates a provocative question: to what extent is the weapon development this century linked to the increased proportion of civilians injured? This poses a further question: does increased ease with which a weapon can be used to achieve military objectives (military efficiency) increase the potential for civilian casualties? ${ }^{\text {?2 }}$

The hallmarks of countries where most modern wars are fought are poverty, destroyed social and economic infrastructure, and availability of a variety of weapons. ${ }^{1}$ Disciplined armies train their soldiers in the laws of war, which include respect for the civilian population; by contrast, modern wars tend to be fought by forces that are poorly trained and may even target civilians. Another feature of these modern wars is that competent medical facilities are few or non-existent. Care of those wounded during these conflicts has fallen to international aid agencies. One of the few sources of data about casualties in these wars is the hospitals run by the International Committee of the Red Cross. We examined all the data held by the Red Cross on wound injuries treated in its hospitals from January 1991 to July 1998 to explore these two questions. We also examined data from the Kabul hospital during a period when the city of Kabul was under siege.

\section{Patients and methods}

\section{Database}

The wound database of the International Committee of the Red Cross was installed in January 1991 and originates from a system of data collection originally 
designed to give the organisation an indication of the activities of its independent hospitals. All patients wounded in war who have been admitted to the Red Cross hospitals of Peshawar and Quetta (Afghan border of Pakistan), Kabul and Khandahar (Afghanistan), Khao I Dang (Cambodian border of Thailand), Butare (Rwanda), Novi Atagi (Chechenia), and Lokichokio (Sudanese border of Kenya) have routinely had a data form filled out on their death or discharge from surgical wards. Age and sex, the cause of injury, and the time lapsed between injury and admission are recorded for each patient. Patients are not asked whether they are combatants.

\section{Kabul}

The Red Cross hospital in Kabul, Afghanistan, functioned independently until the fall of the communist government in mid-1992. It was the first of its kind to be in a city under siege rather than removed from the conflict over a border. Where the hospital was working was thus the same place as where patients were wounded. Patients were wounded in the city itself and at the front lines surrounding the city. Those wounded among the rebel forces besieging the city had access to the first aid posts run by the Red Cross outside the city and then were transported to the hospital by the organisation's ambulances; few reached the hospital within six hours. By contrast, those wounded in the city reached hospital usually within an hour and certainly within six hours. ${ }^{13}$ Patients in the city were representative of victims of urbanised, modern conflict; many were clearly civilians.

\section{Analysis}

The patients' data were analysed by age and sex and the cause of injury. As in previous studies, ${ }^{569}$ women and girls, boys (under 16 years of age), and men of 50 or more were considered to be civilians. In this study bullet indicates any gunshot wound, fragment indicates injury from shell, bomb, or mortar, and mine indicates injury from an antitank or antipersonnel mine. Differences in the proportion of people injured by bullets in comparison with mortars or mines were evaluated using the $\chi^{2}$ test.

Table 1 Numbers of patients admitted to all Red Cross hospitals by cause of injury

\begin{tabular}{lcc} 
Cause of injury & No of patients & No (\%) of civilians* \\
\hline Bullet & 8432 & $1578(18.7)$ \\
\hline Fragment† & 5759 & $1962(34.1)$ \\
\hline Mineł & 4686 & $1445(30.8)$ \\
\hline Total & 18877 & $4985(26.4)$
\end{tabular}

*Women and girls, boys (under 16 ), men aged $\geqslant 50$. †Includes shells, bombs, and mortars. ‡Antitank and antipersonnel.

Table 2 Numbers of patients admitted to Red Cross hospital in Kabul within six hours of injury by cause of injury

\begin{tabular}{lcc} 
Cause of injury & No of patients & No (\%) of civilians \\
\hline Bullet & 699 & $273(39.1)$ \\
\hline Fragment† & 837 & $507(60.6)$ \\
\hline Mine $\ddagger$ & 476 & $262(55.0)$ \\
\hline Total & 2012 & $1042(51.8)$ \\
\hline
\end{tabular}

*Women and girls, boys (under 16 ), men aged $\geqslant 50$. †Includes shells, bombs, and mortars. ¥Antitank and antipersonnel.

\section{Results}

A total of 27825 patients were registered between January 1991 and July 1998. Of these, 18877 were injured by bullets, bombs, shells, mortars, or mines; the rest were admitted because of burns or blunt trauma or for reconstructive surgery. Of the 18877 who were injured by weapons, 2012 were admitted to the Kabul hospital in less than six hours after injury.

Table 1 shows the numbers of people who were injured by bullets, mortars, or mines and the proportions who were civilians. Table 2 shows the same information for patients admitted to Kabul hospital within six hours of injury. In all the hospitals and in Kabul under siege a significantly greater proportion of civilians had been injured by mortars or mines than by bullets $(\mathrm{P}<0.001)$.

\section{Discussion}

\section{Limitations}

These data are probably the best available means of examining the direct human impact of the use of weapons in modern conflicts. Their validity and reliability have not been ascertained by formal independent means because of the constraints imposed on collecting them under field conditions, and there is obvious scope for misclassification. Some patients lie about how they were injured to gain admission to hospital or they may not know exactly what injured them, and our means of classifying patients as combatants or civilians is a potential source of error. Nevertheless, any misclassification in this setting is likely to have underestimated the numbers of civilians. The number of men aged 16-49 who were civilians was probably greater than the combined number of women, boys, and men over 49 who were combatants. Thus the proportion of civilians is almost certainly higher than the proportions given here.

\section{Weapon type and civilian injuries}

To our knowledge, the implications for civilian injuries brought by different weapons has not been fully examined before. These data show that factors relating to both the design of weapons and the discipline or intent of the user have implications for civilian injuries.

The higher proportion of civilians injured by fragments rather than bullets is significant and may be exaggerated in a different context such as a city under siege, where at least $61 \%$ of those injured by fragments were civilians. Likewise, the proportion of civilians injured by mines is significantly higher than that injured by bullets. There must therefore be a link between the technology of weapons and who is wounded. Two points are important when considering the nature of this link.

Firstly, weapons that fragment can easily injure more than one person, and mines remain after the conflict, both increasing the likelihood of civilian injuries.

Secondly, compared with using a rifle, there is distance and no visual contact between the user and the victim in space (shells, bombs, and mortars) or time (mines). The user thus feels less responsible for his or her actions, the psychology of the user perhaps changing with the weapon used. ${ }^{14}$ At the time these data were collected those besieging the city of Kabul reported 
Key messages

- During war, mines and fragmenting munitions (mortars, bombs, and shells) are more likely than bullets to injure civilians

- Civilians in a city under siege are particularly at risk of being injured by weapons whose users are not able to see the victim

- The inherent nature of weapons may be a factor in determining whether civilians are killed or injured

- There is a need for greater respect for the Fourth Geneva Convention and for greater controls on weapons being transferred to untrained and undisciplined forces

that they kissed the rockets, shells, and mortars before they were loaded so that God would decide whether they hit the enemy.

Both increased destructive force and increased distance between user and victim are features of military efficiency of a weapon system. This study supports the proposal of a fundamental principle: with greater military efficiency of weapons comes an inherent and increased potential for injuring civilians. ${ }^{12}$ The data from Kabul are pertinent to the global trend of urbanisation of societies and show how the potential of any weapon to injure civilians is exaggerated in urban settings.

Weapons, law, and preventive medicine

The process of making or promoting policy and law entails analysing data which clarify the nature of the problem that the policy or law is trying to avoid. International humanitarian law is no exception. These data show that the number of civilian injuries is related not only to whether weapons are in the hands of untrained and undisciplined users but also to the type of weapon in those hands. This argues for a greater need to control the transfer of weapons of increasing military effi- ciency and warrants urgent and serious examination of states' obligations under international humanitarian law in relation to arms transfer. Such an examination should naturally follow the precedent set by the drawing up of a treaty banning the production, stockpiling, transfer, and use of antipersonnel mines. The medical profession has a responsibility to examine the global weapon problem as a health issue ${ }^{12}$; this is a form of preventive medicine.

Contributors: HOS first found variation in age and sex of patients according to cause of injury on examining the ICRC surgical database. RMC had the core idea that the weapon type may lend itself to indiscriminate use, formally re-examined the database, and wrote the paper. RMC is guarantor for the study.

Funding: No additional funding.

Competing interests: None declared.

1 Sidel VW. The international arms trade and its impact on health. BMJ 1995;311:1677-80.

2 Coupland RM. The effects of weapons on health. Lancet 1996;347:450-1.

3 Bowyer GW. Management of small fragment wounds in modern warfare: a return to Hunterian principles? Ann R Coll Surg 1997;79:175-82.

4 Sellier KG, Kneubuehl BP. Wound ballistics. Amsterdam: Elsevier, 1994.

5 Coupland RM, Korver A. Injuries from antipersonnel mines: the experience of the International Committee of the Red Cross. BMJ 1991;303:1509-12.

6 Coupland RM. Hand grenade injuries among civilians. JAMA 1993;270:624-6

7 Andersson N, Palha da Sousa C, Paredes S. Social cost of land mines in four countries: Afghanistan, Bosnia, Cambodia and Mozambique. BMJ 1995;311:718-21.

8 Ascherio A, Biellik R, Epstein A, Snetro G, Gloyd S, Ayotte B, et al. Deaths and injuries caused by landmines in Mozambique. Lancet 1995;346:721-4.

9 Jeffrey S. Anti-personnel mines: who are the victims? J Accid Emerg Med 1996;13:343-6.

10 Garfield RM, Neugut AI. Epidemiological analysis of warfare: a historical analysis. JAMA 1991;226:688-92.

11 Prokosch E. The technology of killing. London: Zed Books, 1995

12 International Committee of the Red Cross. The medical profession and the effects of weapons: the symposium. Geneva: ICRC, 1996.

13 Coupland RM. Epidemiological approach to the surgical management of the casualties of war. BMJ 1994;308:1693-7.

14 Grossman D. On killing: the psychological cost of learning to kill in war and society. Boston, MA: Little, Brown, 1995.

(Accepted 29 September 1998)

\title{
Circumstances around weapon injury in Cambodia after departure of a peacekeeping force: prospective cohort study
}

\author{
David R Meddings, Stephanie M O'Connor
}

\section{Editorial by Smith \\ Unit of the Chief Medical Officer, International \\ Committee of the Red Cross, \\ 19 avenue de la Paix, 1202 Geneva, Switzerland \\ David R Meddings epidemiologist}

continued over

BMJ 1999;319:412-5

\begin{abstract}
Objective To examine the circumstances surrounding weapon injury and combatant status of those injured by weapons.

Design Prospective cohort study.

Setting Northwestern Cambodia after departure of United Nations peacekeeping force.

Subjects 863 people admitted to hospital for weapon injuries over 12 months.

Main outcome measures Annual incidence of weapon injury by time period; proportions of injuries inflicted as a result of interfactional combat (combat injuries) and outside such combat (non-combat injuries) by combatant status and weapon type.

Results The annual incidence of weapon injuries was higher than the rate observed before the peacekeeping operation. $30 \%$ of weapon injuries occurred in contexts other than interfactional combat. Most commonly these were firearm injuries inflicted
\end{abstract}

intentionally on civilians. Civilians accounted for $71 \%$ of those with non-combat injuries, $42 \%$ of those with combat related injuries, and $51 \%$ of those with weapon injuries of either type.

Conclusions The incidence of weapon injuries remained high when the disarmament component of a peacekeeping operation achieved only limited success. Furthermore, injuries occurring outside the context of interfactional combat accounted for a substantial proportion of all weapon injuries, were experienced disproportionately by civilians, and were most likely to entail the intentional use of a firearm against a civilian.

\section{Introduction}

In many areas of the world military weapons are widely available. ${ }^{12}$ This has been argued to contribute to regional instability, increased civilian injuries, and violence that is not directly related to interfactional combat. ${ }^{34}$ 